urine-probably resulting from general heightened bloodpressure. (2) Spartein, with diminished secretion-in health at least. (3) Strophanthin causes slight temporary contraction, with no marked increase of secretion. (4) Apocynëin, similar temporary contraction, and no definite increase of secretion. (5) Turpentine, (6) adonidin, and (7) varium chloride give similar results.

In conclusion, it seems to us that the plethysmographic method of experimentation is a valuable one for determining the exact action of drugs on the circulation, and one that deserves more attention than it has hitherto attracted.

Henrietta-street, Cavendish-square, W.

\section{NON-TUBERCULATED LEPROSY WITH LOCAL ASPHYXIA BETWEEN THE ANASTHETIC PATCHES.}

B Y B E A V N R A K E, M.D. LoND., IIEDICAL SUPERIYTENDENT OF THE TRINIDAD LEPER ASYLUM.

LEPROSY, as is well known, furnishes frequent and typical examples of the various trophic lesions so often discussed in Europe. It is, however, in connexion with the more obscure condition known as local asphyxia, or Raynaud's disease, that $I$ venture to relate this case. It is unique in my experience of leprosy, and derives additional interest from the fact of its occurring in a fair-skinned, intelligent European.

Chevy A-_-, aged forty-five, born in France, was admitted to the Trinidad Leper Asylum on May 19th, 1883. He had served in the Crimea and in various other parts of the world. I examined him from time to time, and was surprised to find how little progress the disease was making. Beyond localised areas of anæsthesia in the extremities, there was no evidence of leprosy. The anæsthetic skin was at this time of exactly the same colour as the unaffected skin. He was an active man, constantly employed in making boots or in work about the asylum. On returning from Europe in September, 1886, I was, however, struck by a remarkable change which had taken place during my absence. The following are the notes then taken.

Oct. 1st, 1886: The anæsthetic patches are of the normal white colour; all the rest of the skin is of a dusky red. On pressure with the finger the congestion disappears. On drawing the nail across the skin the dark colour vanishes, then reappears, and afterwards a distinct bright-red wheal is observed in the line of the finger. He says the congestion disappears when bathing in the sea. He complains of much pain in the limbs, especially in the palms of the hands. The fingers are anæsthetic, and becoming stiff.-25th: He has been trying friction with gurjun liniment, but says the fingers are stiffer and more paintul. The left medirn nerve was therefore stretched under chloroform. The nerve was found to be thickened. Some juice was collected from the exposed nerve on a cover glass and examined with magenta, but no bacilli were found. - $29 \mathrm{th}$ : He says there is a sleepy feeling in the palm of the hand in place of the anrsthesia. When tested with the eyes shut, he refers the impact of a substance to one side of the point actually touched.Nov. 12th: Now that the rain is falling, the colour of the skin between the taches has turned to a dusky reddish blue. He says the fingers feel cold, and that sometimes the skin is almost black during the rains. There is now no change whatever in colour or sensation in the parts supplied by the median nerve operated on.-Feb. 14th, 1887: IHe has been rubbing the arms with a 10 per cent. solution of ichthyol in olive oil. The dark colour is a little lighter, but there is no change in the anæsthesia.March 14th: The congestion of the skin is almost gone. Has had dysentery for the last month. Complains of a cold sensation in the abdomen.-April 16th: He has been losing much bright blood from the bowel lately. Is found to have a prolapse of the rectum, with congested ulcerated surface. He was given chloroform, and the lower two inches of the rectum were drawn down and everted. The mucous membrane was cauterised linearly in the long axis of the bowel with a black-hot wire. It was then rubbed over with fuming nitric acid and tannin applied.-29th : Since the operation he has passed a good deal of blood from time to time. This has been checked by injertions of nitrate of silver and of opium, and by turpentine by the mouth. The violet colour between the tacbes on the upper extremities has gone, leaving dusky-red patches.--May 4th: Sitting up; walked yesterday. Had diarrboa, but no more blood. 'lo repeat turpentiue.-6th: Has passed hardly any urine since lasê night. About four ounces of clear urine, smelling strongly of turpentine, were drawn off by catheter. Burning sensation over bladder. - 18th: Has had fever every day at noon lately, which was relieved somewhat by ammonium picrate. Urine high coloured; a trace of albumen. Edems of hands and feet. Frequent diarrhœa, but not much blood. Looks better in face.-19th: Died at 2 P.M.

The necropsy, next day, showed an enormous liver, weighing $83 \mathrm{oz}$, and containing five distunct abscesses; the total amount of pus was estimated at from two to three pints, Weight of spleen $18 \mathrm{oz}$; simple hypertrophy. Weight of kidneys $9 \mathrm{oz}$; cortices somewhat thinned and granular on surface. Aorta very atheromatous. No recent bæmorrhage or ulceration was found in the rectum, the ulcers appearing to be cicatrised; but the rest of the large intestine was invaded by numerous more or less circular and sharply defined ulcers. The median nerves were thickened, but no difference was found between that which had and that which had not been stretched. The right cervical sympathetic and ganglion of the vagus were dissected out, but no change was found. Sections also showed no change under the microscope. Magenta showed numerous cells in the median nerve, staining very dark, and apparently st uffed with bacilli, also some free bacilli. Numerous bacilli, both free and in cells, were found in a scraping from the superior cervical ganglion of the sympathetic.

This case revealed a mass of morbid anatomy, hardly an organ being sound. The condition of the skin, however, is the chief point of interest. The strange feature in the case is the appearance of the congestion between the taches four years after the onset of the anxsthesia. Was this due to a tresh increase of bacilli in the mixed nerves, leading to invasion of the sympathetic fibres? But if so, why is this condition not more common, for the thickened condition of the median is common enough in leprosy, as also the discovery of bacill in the affected nerves. I thought, therefore, that possibly a dissection of the cervical sympathetic might throw some light on the matter. No naked-eye change was found, but the microscope showed numerous bacilli in a scraping from the superior cervical ganglion. This is in contrast to results obtained in the cerebro-spinal centres; I have failed to find bacilli in brain or cord, nor has their occurrence there, I believe, been recorded. The disappearance of the congestion after prolonged hæmorrhage from the bowel was a point of interest. Whether the connexion was sympathetic or more direct I cannot say. Altogether the case struck me as presenting a remarkable resemblance to the earlier stages of Raynaud's disease, and as being sufficiently obscure and rare to place on record. Trinidad.

\section{Clinical allotes:}

\section{MEDICAL, SURGICAL, OBSTETRICAL, AND THERAPEUTICAL.}

\section{CASE OF TRACHEOTOMY.}

By J. Crawford Renton, M.D. ED,

SURGEON TO THE EYE INFIRMARY AND TO THE DISPENSARY OF THB WRSTERN INGTRMAARY, GLASGOW.

THE following case presents several points of interests and is, I think, worthy of record.

J. C-C, aged seventeen months, was first seen on January 22nd, 1886, complaining of symptoms of laryngitis, with absence of the typical cough. The child had been ill for six days, the mother stated, but to-day she had observed some difficulty in breathing, which caused her some alarm. Pulse 120 ; temperature $101^{\circ}$. No cervical swelling, and nc exudation on the fauces or tonsils. The usual remedies were resorted to, and were continued until January 26th when the child had a severe spasmodic attack, with obstruction to the breathing, lasting for half an hour afterwards. Tracheotomy was advised, and in this Dr. Beatson concurred. The operation, however, was delayed, as the child 
seemed slightly better. Mercurial inunction was had recourse to, as we thought it possible that some specific affection of the larynx might be causing the hoarseness and spasms. On January 31 st the spasms were more frequent, and there was greater difficulty of breathing. $\Lambda$ ssisted by Dr. Beatson, I opened the trachea, with immediate relief to the urgent symptoms. There was no swelling about the throat, and no special difficulty in performing the operation. One of the late Dr. Foulis's tubes was used, and the breathing was perfect until the inner tube was inserted, when a apasm immediately took place, so that it (the inner tube) wes removed. The child progressed favourably for three days, when suddenly an abscess burst into the trachea and death took place. When the nurse was dressing the child giter death, she noticed something sharp and prominent at the left side of the neck, an inch below and to the outer side of the wound, and drew my attention to it. On introducing my finger into the tracheal wound, I found behind it the outline of a foreign substance, not in the trachea, but sridently between it and the cesophagus. Cutting down on the external sharp point, a pin was extracted measuring two inches in length, and from its appearance it was evident that it had belonged to a brooch or safety pin. I was allowed to examine the throat, and found that an abscess existed between the trachea and gullet, which had burst into the windpipe and caused the fatal result. The larynx and trachea were quite healthy, there being no evidence of any affection of the vocal cords.

Remarks.-On explaining the cause of death to the child's mother, she stated that three months previously, while from home, a brooch was found without the pin, which had been broken, and, like many other children, our little patient often put beads, pins, \&c., into her moutb, and while in the country she may have swallowed the brooch pin. It is quite possible for a pin to remain in the œsophagus for a considerable time without causing any irritation, especially if it is fixed perpendicularly. Some displacement takes place and an abscess gradually forms, pressure on the rrachea causing spasm, which in the present case necessitated tracheotomy; finally the abscess burst and disiplaced the pin into the position in which we found it. This case illustrates the importance of bearing in mind the possibility of foreign bodies in the larynx, trachea, and resophagus producing spasm and difficulty of breathing, aven where there is no history of such being swallowed to guide us. An examination of the larynx with the laryngoscope might have aided us, but as we felt certain that we were either dealing with an inflammatory or specific affection of the windpipe, we deemed it unnecessary to give the child chloroform for that purpose.

PARALYSIS OF THE ABDUCTORS OF THE VOCAL CORDS.

BI A. LEGGE ROE, L.K.Q.C.P.I, L.R.C.S.I.,

RESIDENT SURGEON, HULL AND SCULCOATES DISPENSARY.

I READ with much interest the paper by Dr. Gordon Holmes in THE LANCET of the 22nd and 29 th ult. During the last few weeks I have had under my care at the Hull and Sculcoates Dispensary two well-marked cases of this somewhat rare disease. The first was a man aged fortyfive, who complained of marked inspiratory difficulty, which laryngoscopic examination proved to be caused by bilateral paralysis of the abductor muscles. Careful examination of the chest gave negative results. Unfortunately, being pressed for time, a complete history was not then obtained, and the man on being informed of the serious nature of the affection ceased to attend, and has beer lost sight of.

The second case, a woman aged fifty-eight, is at present under treatment. She gives a most clear history of an attack of laryngitis twenty years ago, which was shortly followed by difficulty in breathing, most marked on exertion or when she had a cold. This difficulty has remained ever since. Laryngoscopic examination revealed complete paraiysis of the abductor muscles; the vocal cords do not separate more than two millimetres on inspiration, and on forcible inspiration are almost driven together by the in-rushing air. Toice unaltered; soncrous inspiration present during quiet respiration, very loud during sleep. No enlarged glands, tumour, or other cause of pressure could be discovered.

This case is of interest on account of the clear history of the great length of time the paralysis has existed without calling for operative interf'erence. The eold from which she was suffering when she first presented herself caused great inspiratory difficulty. This has now passed away, and the respiration is comparatively quiet.

Hull.

CASE OF SUPERFETATION.

Bx B. G. GODFREY, L.R.C.P., M.R.C.S.

I was called on Aug. 17th of the present year to Mre. $\mathrm{H}-$ - aged twenty-nine, to attend her in her fourth confinement. She stated she was seven and a half months gone and had been in pain all night, with considerable loss. On examination I found a three and a half months' foetus in the vagina, which came away without difficulty. The uterus was large, rising about two inches above the umbilicus, and I could distinctly feel the movement of another foetus. The placenta did not come away, and all pain ceased. I then left her, as there was no hæmorrhage or pain, and returning in an hour and a half found things in statu quo. This stale of affairs continued for four days, when the pains returned, and the breech of 8 child was born before my arrival. I immediately removed the child, still-born, though the nurse informed me that the legs moved after their delivery. The child must have been quite seven months, as the nails were commencing to form and its weight was $4 \frac{1}{t} \mathrm{lb}$. The placenta of the second child came away naturally, but was followed by a great deal of hæmorrhage; there was no sign of a second after-birth attached to it. Traction on the smaller cord failed to detach its placenta, so $I$ introduced my hand into the uterus and removed it piecemeal; it was completely adherent and attached to the upper zone on the right side, measuring about 3 in. across it was not putrid. All the bleeding immediately ceased, and my patient made an excellent recovery, without a drawback. Balham.

DISLOCATION OF THE FIRST PHALANX OF THE INDEX-FINGER BACKWARDS.

BY E. M. HARRISON, M.R.C.S., \&c.

A Distocation similar to that recorded by Mr. Miller in a recent number of THE LANCET lately came under my observation, and may be worthy of a brief record.

A servant girl came to my surgery one morning, stating that in moving a heavy box her hand had slipped, the palmar surface of the proximal end of the phalanx coming into violent contact with the edge of the box. Since the accident, which happened about a quarter of an hour before I saw her, the finger had been immovable and very painful. There was no difficulty in recognising a backward dislocation of the first phalanx on to the metacarpal bone. This was easily reduced with the thumb of the left hand pressing on the displaced bone and traction on the finger with the right hand. Willowmore, South Africa.

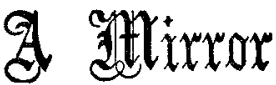

\section{HOSPITAL PRACTICE,} BRITISH AND FOREIGN.

Nulla autem est alia pro certo noscendi via, nisi quamplurimas et moroorum et dissectionum historias, tum aliorum tum proprias collectas habere, et inter se comparare.-MorgatiNI De Sed. et Caus. Morb. lib. iv. Procemium.

\section{ST. MARY'S HOSPITAL.}

TWO CASES IN WHICH THE OPERAIION FOR THE RADICAT CURE OF STRANGULATED INGUINAL HERNIA WAS PERFORMED, AN ATROPHIED TESTIS BEING REMOVED AT THE SAME TIME; RECOVERY; REMARKS.

(Under the care of Mr. EDMUND OWEN.)

THE question of excision of an atrophied testis in cases where operation for strangulated hernia is performed must be left to the discretion of the operator. By the removal of the testis and cord the canal would appear to be more effectually blocked, whilst the removal of the wasted and presumably useless organ does not add materially to the severity of the operation. The best kind of suture to be 